BULLETIN OF PNRPU. GEOLOGY. OIL \& GAS ENGINEERING \& MINING

ВЕСТНИК ПНИІУ. ГЕОЛОГИЯ. НЕФТЕГАЗОВОЕ И ГОРНОЕ ДЕ

ISSN 2224-9923

Volume/TOM 15 №21 2016

http://vestnik.pstu.ru/geo

УДК 622.276

Article / Статья

(C) PNRPU / ПНИПУ, 2016

\title{
MECHANICAL SYSTEM OF LAYER PROTECTION AND TECHNOLOGY OF ITS APPLICATION TO PREVENT CLOGGING OF BOTTOMHOLE FORMATION ZONE IN PERFORMING GEOLOGICAL AND TECHNICAL MEASURES
}

\section{V.V. Pepeliaev, I.L. Korobkov, D.V. Pepeliaev, A.M. Nasyrov ${ }^{1}$, S.V. Galkin ${ }^{2}$}

Perm construction and technological Bureau of technical design and production organization

(21 Akademika Koroleva str., Perm, 614013, Russian Federation)

Institute of Oil and Gas named after M.S. Gutseriev (1 Universitetskaia str., Izhevsk, 426034, Russian Federation)

${ }^{2}$ Perm National Research Polytechnic University (29 Komsomolskii ave., Perm, 614990, Russian Federation)

\section{МЕХАНИЧЕСКИЙ КОМПЛЕКС ЗАЩИТЫ ПЛАСТА И ТЕХНОЛОГИЯ ЕГО ПРИМЕНЕНИЯ ДЛЯ ПРЕДОТВРАЩЕНИЯ КОЛЬМАТАЦИИ ПРИЗАБОЙНОЙ ЗОНЫ ПЛАСТА В ПРОЦЕССЕ ПРОВЕДЕНИЯ ГЕОЛОГО-ТЕХНИЧЕСКИХ МЕРОПРИЯТИИ}

\section{В.В. Пепеляев, И.Л. Коробков, Д.В. Пепеляев, А.М. Насыров ${ }^{1}$, С.В. Галкин ${ }^{2}$}

Пермское конструкторско-технологическое бюро технического проектирования и организации производства (614013, Россия, г. Пермь, ул. Академика Королева, 21)

${ }_{1}^{1}$ Институт нефти и газа им. М.С. Гуцериева (426034, Республика Удмуртия, г. Ижевск, ул. Университетская, 1)

${ }^{2}$ Пермский национальный исследовательский политехнический университет (614990, Россия, г. Пермь, Комсомольский пр., 29)

Received / Получена: 12.09.2016. Accepted / Принята: 25.10.2016. Published / Опубликована: 02.12.2016

Ключевые слова:

призабойная зона пласта, геолого-технические мероприятия, жидкость глушения, кольматация, скважинные осложнения, насосное оборудование, механическии комплекс отсекатель, шламоуловитель.

Key words: bottomhole formation zone, geological and technical measures, killing fluid, clogging, well complications, pump units, mechanical system of layer protection, shutoff valve, sludge trap.

\begin{abstract}
Одной из важных задач эффективной эксплуатации скважин нефтяных месторождений является предотвращение кольматации призабойной зоны пласта в процессе проведения различных геолого-технических мероприятий. В качестве одного из перспективных средств предотвращения падения продуктивности пласта предложена технология с использованием забойных клапанов-отсекателей. Сущность технологии заключается в применении глубинного комплекса защиты пласта, который герметично монтируется в скважине, разделяя продуктивный пласт и зону размещения насосного оборудования. Проведенный анализ показал, что известные варианты компоновок с клапанами-отсекателями (системы с гидравлическим, механическим, электрическим приводом) не позволяют проводить исследования по контролю за разработкой эксплуатируемого объекта. Соответственно, ни одна из

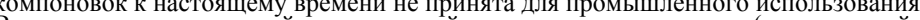

В статье предложен новый механический комплекс защиты пласта (включающий в том числе и клапан-отсекатель забоя), обеспечивающий герметичное разобщение продуктивного пласта и области закачки жидкости глушения при нали крана, в закрыном положении шар прижимаеся к седлу давлением, чюо создает сопротивлние его открытию. С дел дес работы устройства при наличии скважинных осложнений. Для ренения данной проблемы в состав оборудования включен специалны разисцисти от различного числа остановок и при различных кон. Вытрачия т расчеты заи

В результате расчетов сделаны выводы о выполнении условий прочности для заданных геометрических размеров в пар материалов сталь-полиамид и сталь-Zеdех.

Предлагаемая конструкция устройства гарантирует надежное разобщение подпакерного и надпакерного Предлаг пространств, предотващая попадание жидкости ол установкой в зависимости от скважинных условий.
\end{abstract}

One of the important tasks of effective well operation in oil fields is to prevent clogging of bottomhole formation zone in the process of various geological and technical measures. As one of the most promising means to prevent reservoir productivity decreasing a technology using downhole shutoff valves has been proposed. Summary of the technology consists in application of a deep reservoir protection system, which is hermetically mounted in the well and dividing the productive formation area and pumping equipment placement. The analysis showed that the known shutoff valves configurations (systems with hydraulic, mechanical, electric drive) does not allow to carry out research on monitoring the development of operated object. Accordingly, none of the configurations has not been accepted for industrial use so far. The paper proposes a new mechanical reservoir protection system (including the bottomhole shutoff valve), providing a hermetic separation of productive reservoir and area of killing fluid injection when the differential pressure is up to 10 $\mathrm{MPa}$. The basis of the shutoff valve construction is the principle of ball valve, in closed position the ball is pressed to valve seat by pressure, which creates a resistance to its opening.

In order to achieve a high equipment's operating time in design a special attention was paid to ensure device operation with the presence of well complications. To solve this problem a special sludge trap was included in the equipment and it was placed between the hollow plunger and the pump unit with a back pressure valve and a perforated pipe inside. Calculations of sludge trap filling were made according to the different number of stops and at various concentrations of mechanical impurities.

As a result of calculations conclusions about the strength conditions fulfillment for geometric dimensions specified for pairs of steel-polyamide and steel-Zedex materials were made.

Proposed device construction ensures a reliable isolation between under and above packer space, preventing ingress of killing fluid in the bottomhole formation zone. Universal equipment configuration extends its application area and the possibility of its use in combination with any pump unit depending on well conditions.

Valerii V. Pepeliaev - PhD of Technical Sciences, Associate Professor, Director (tel·+007 34223916 04, e-mail: pepelyaev@tehproekt perm.ru). The contact person for correspondence.

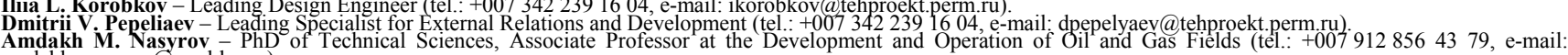

Sergei V. Galkin - Doctor of Technical Sciences, Associate Professor at the Department of Oil and Gas Technologies (tel.: +007 342 19 81 18, e-mail: doc_galkin@mail.ru).

Пепеляев Валерий Витальевич - кандидат технических наук, доцент, директор (тел.: +007 34223916 04, e-mail: pepelyaev@tehproekt.perm.ru). Контактное лицо для переписки.

Коробков Илья Леонидович - ведущий инженер-конструктор (тел.: +007 342239 16 04, e-mail: ikorobkov@tehproekt.perm.ru).

Пепеляев Дмитрий Валерьевич - ведущий специалист по внешним связям и развитию (тел.: +007 3422391604 , e-mail: dpepelyaev@tehproekt.perm.ru).

Насыров Амдах Мустафаевич - кандидат технических наук, доцент кафедры разработки и эксплуатации нефтяных и газовых месторождений (тел.: +007 91285643 79, e-mail: amdakh_nasyrov@rambler.ru). doc galkin@mail.ru). 


\section{Introduction}

Currently, a significant proportion of wells on the Russian oil companies fields are at the final stage of operation. Often there are a reservoir productivity decreasing after its killing during the repair work, repair and insulation works column, replacing the downhole pumping equipment, reservoir study, etc. in such wells. According to statistics of subsidiaries PJSC "NC "Rosneft"'" approximately $22 \%$ well starts after the current wells and workover occur with the flow rate loss.

The infiltration of technological salt solutions killing fluids in the bottomhole formation zone (BHFZ), their interaction with the rock-forming minerals and the reservoir fluids are the reasons for the productivity loss due to deteriorated reservoir properties [1]. Swelling clay material rock, reservoir clogging with killing fluid solids, lossing of insoluble salts by mixing reservoir and killing fluid are the processes of interaction.

The use of polysaccharide fluids for killing wells is one of the options for the saving of reservoir properties in the course of technological operations today. They include inhibitors to prevent swelling of clay minerals and precipitation of water insoluble salts and to ensure reservoir productivity saving [2].

Another way to deal with BHFZ clogging is a well killing technology by blocking special trains (block-packs), which control the liquid absorption in the reservoir [3]. The composition is a specially selected system, its components make it possible to create a dense filter cake in the perforation zone. The cake is impermeable to water filtration, it protects the reservoir from the deep fluid killing penetration. The blocking compound is removed from the well by minimum drawdown pressure and is carried on the surface by reservoir fluid when well is started after repair.

Relevant area of saving well productivity after repair is the use of hydrocarbon killing liquid [4]. For example, inverse emulsion, where dispersion medium is degassed and product oil, diesel, bitumen distillate and other hydrocarbons, dispersed phase is water solutions of salts (or acid and other reagents). A high compatibility with the collectors is significant advantage of such a composition.
At the same time all of these technologies can be considered to reduce clogging of the BHFZ. Using bottomhole shutoff valve technology is more effective preventing metod of reservoir productivity falling as a geological and technical measures result. This tecnology use deep equipment, wich is hermetically mounted in the well, and divides the productive reservoir and pumping equipment placement and has two work positions. In the first position during the drainage an inner channel of shutoff valve is open, allowing pump connection with operated reservoir. In the second position during repair work the inner channel is shut that isolate BHFZ from the killing fluid above shutoff valve.

There are different options of equipment with shutoff valves, which can be divided into systems with hydraulic [5-9], mechanic [10] and electric [11, 12] drive of shutoff valve. Its co-operation with a particular type of pump is a significant disadvantage of the options. Moreover, designed equipment is not allowed to research the control development of operated reservoir in accordance with RD 153-39.0-109-01 [13]. It should also be noted that none of these equipment is not been accepted for industrial use. Thus, the development of technical devices for protection BHFZ against the killing fluid effect is a relevant task in the future and in the present.

\section{Problem statement}

A concept is proposed and a mechanical protection reservoir complex (MPRC) is developed, that includes shutoff valve in this paper. Technical characteristics of MPRC focus on geological and technical development conditions of company PJSC "NC "Rosneft"" and suggests a wide range of depth and intervals set maximum curvature $(600-3500 \mathrm{~m})$, fluid flow rate (5-600 $\mathrm{m}^{3} /$ day), water cut production wells (0-99\%), bottomhole pressure (10-200 atm) and reservoir pressure (25-280 atm), reservoir temperature $\left(20-105{ }^{\circ} \mathrm{C}\right)$ and oil viscosity $(0,1-100,0 \mathrm{cPs})$ gas-oil ratio $\left(10-2000 \mathrm{~m}^{3} / \mathrm{t}\right)$, the content of suspended particles $(0-100 \mathrm{mg} / \mathrm{l})$.

One of the key design requirements of developed equipment is hermetic separation productive reservoir and injection killing fluid if the differential pressure available up to $10 \mathrm{MPa}$. 
MPRC was included serial packer type PM (A1)-F (JSC TD "NKMZ"), that showed high reliability operating in various downhole conditions, as well as specially designed shutoff valve, its ball valve minimizes the risks of incomplete close and availability leakage through its internal channel.

The universality concept is adopted in designing MPRC (installing electrical submersible pump, electrical screw-type pump, rod well pump), ie it has an opportunity to work with any standard deep well pumping equipment (installing electrical submersible pump, electrical screw-type pump, rod well pump), the shutoff valve opening should not be carried out by the help of structural elements specific pumping unit (power cable, telemetry system, the rod string, etc.). In this regard, as a drive mechanism for opening the valve internal channel mechanical pressing on its work features producing string (PS) is selected.

To carry out control development of operated reservoir in accordance with the RD 153-39.0-109-01 [13] without removing the entire system there is endto-end channel, its geometric dimensions allow the descent of geophysical instruments, as well as sufficient for the descent equipment for processing BHFZ, including $33 \mathrm{~mm}$ diameter flexible.

One of the possible complications during the operation of equipment is "seeding" of packer by mechanical impurities contained in the well fluid, with the potential risk of unrecovered downhole equipment. MPRC includes a special assembly that prevents settling of mechanical particles on device elements to minimize this risk.

In addition, design provids the following requirements for easy use:

- installation of the valve mechanism for one tripping;

- there is isolating device to detach PS;

- installation and dismantling of standard equipment by the current and workover crews;

- the ability to extract the drive unit for its revision or replacement;

- funcshionality of the valve assembly is independent of its inclination to the zenith.

The design of the device has been designed taking into account the requirements of RS 07601-03 in order to ensure safe operation [14].

\section{Features design and equipment operation}

In accordance with the requirements MPRC version is adopted and it consists of the following main elements: a packer, shutoff valve, the isolating device, the perforated pipe, back pressure valve, pressure hollow rod and technology valve. Installation of equipment is made in one tripping.

Installing the valve assembly (Fig. 1a) on the PS shutoff and underlying at a given depth packer are descented and instaled. With the use of isolating device PS is disconnected from equipment (shutoff valve and a packer) and is carried out its tripping out. Shutoff valve is in the closed position (see Fig. 1b).
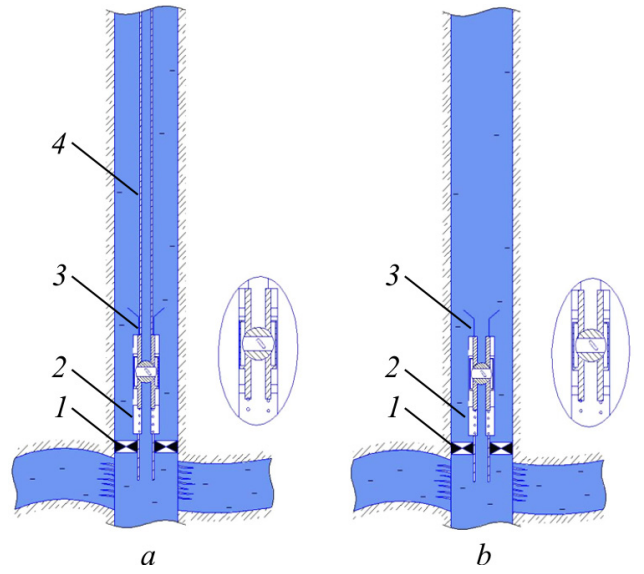

Fig. 1. Valve device installation: $a$-tripping on the producing string, $b$ - producing string tripping out; 1 - packer, 2 - shutoff valve, 3 - isolating device, 4 -producing string

During pumping equipment installation (Fig. 2a) following device is descented on the PS (from top to bottom): pump assembly, a perforated pipe, back pressure valve, pressure hollow rod. The annulus and tubing are filled with killing fluid to prevent oil and gas shows. The descent is carried out before the rod entering into the shutoff valve catcher. At the offloading beginning rod entering into the catcher is controlled. The back pressure valve is closed. After fit and achieve offloading hollow rod opens feedthrough channel of shutoff valve, the hollow rod is sealed inside shutoff valve, as the result through the inner channel of the hollow rod and the perforated pipe under packer space is communicated with above packer space. After pump starting killing fluid 
level falls, under packer pressure becomes higher then killing fluid pressure, the back pressure valve is opened. Reservoir fluid enters the annulus above the packer through the internal channels of the packer, shutoff valve, a hollow rod, back pressure valve and the perforated pipe, where it is carried out by the pump unit (see Fig. 2b).

In case of pump unit replacement the annulus is filled with killing liquid (Fig. 3a). In this case the back pressure valve closes.
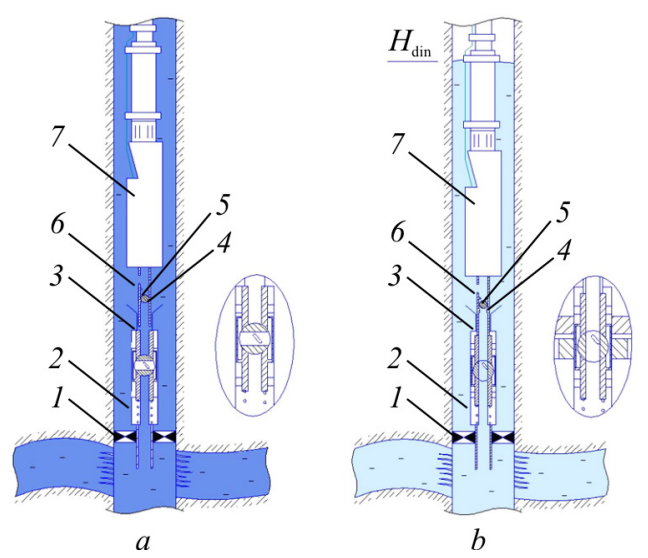

Fig. 2. Installation and pumping equipment starting: $a$ - rod entring into catcher, $b$ - equipment starting; $H_{\text {din }}$ - the dynamic fluid level in the well; 1 - packer, 2 - shutoff valve, 3 - isolating device, 4 - hollow rod, 5 - back pressure valve, 6 - perforated pipe, 7 - pumping unit
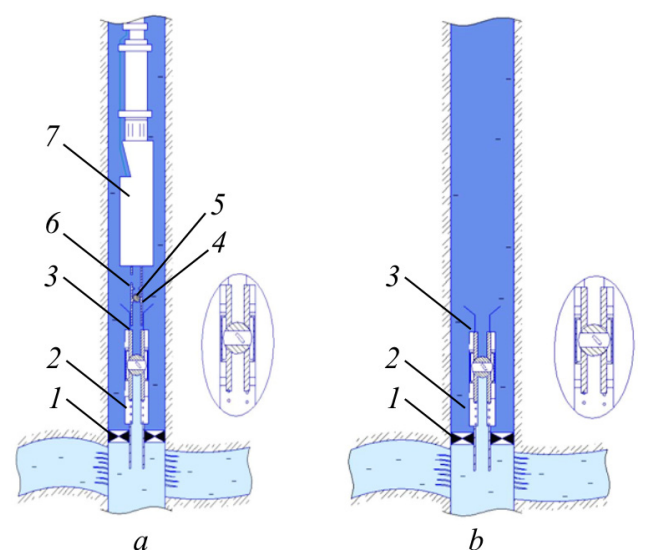

Fig. 3. Equipment Removal: $a$ - filling annulus with killing liquid, $b$ - tripping out equipment; 1 - packer, 2 - shutoff valve, 3 - isolating device, 4 - hollow rod, 5 - back pressure valve, 6 - perforated pipe, 7 - pumping unit

The wellhead equipment is dismanted, then hollow rod is put out of the shutoff valve by PS stretch the tubing stretched, and the feedthrough channel of shutoff valve is closed, above packer space is disconnect from under packer space. Tripping out the PS "pumping unit - perforated pipe the back pressure valve - pressure hollow rod" the annulus filling by killing fluid is controled. The remaining in the well packer and closed shutoff valve safely disconnect above packer space from under packer space (see Fig. 3b).

If the research under packer space is necessary, PS with a pressure hollow rod is descented (Fig. 4a) and full bore protection device during filling PS shutter positioned above the rod (PS valve). At the offloading beginning the rod entering in the shutoff valve catcher is controlled.
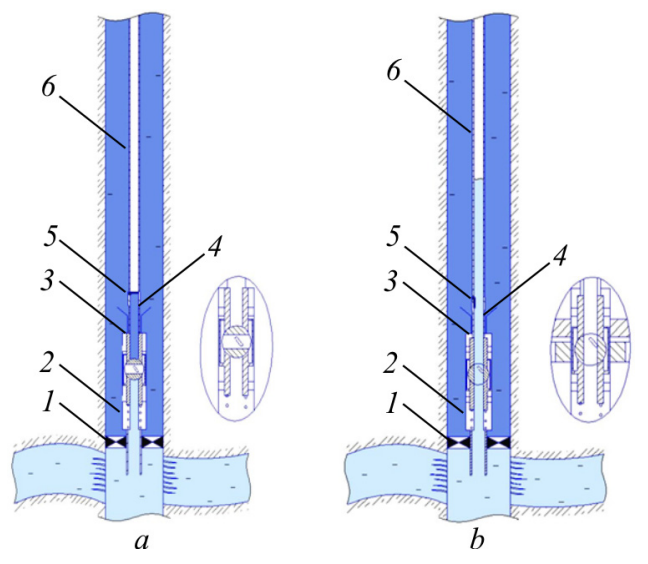

Fig. 4. Researching: $a$-descent of producing string, $b$ - shutoff valve opening; 1 - packer, 2 - shutoff valve, 3 - isolating device, 4 - pressure hollow rod,

5 - producing string valve, 6 - producing string

Entering rod is sealed in the catcher. PS fit is maden and wellhead assembly with geophysical lubricator is installed. During the operation closed valve of PS does not allow killing fluid fill the PS. Further PS offloading in the catcher is carried out. After fitting and achieving the required offloading hollow rod opens shutoff valve feedthrough channel the hollow rod seals inside shutoff valve, the PS valve opens, in this case above packer and under packer space are communicated (see Fig. 4b).

The fluid level in PS depends on the reservoir pressure, and annulus killing fluid does not enter into the reservoir (in this layout hollow rod, the PS valve inner channel and PS form a hermetic channel to the mouth). Thus, a channel for running appliances or other equipment is realized, which sealing is carried out at the mouth lubricator. After 
the research tension of the PS is carried out by rig. Hollow rod is come out of the the shutoff valve catcher, rotary mechanism is closed by the return spring. While lifting equipment killing fluid refilling to the annulus is controlled. The remaining in the well packer and closed shutoff valve safely uncouple under packer and above packer space (see Fig. 3b).

\section{Measures to ensure the functionality of equipment}

In order to achieve high equipment functionality at designing special attention was paid to ability of working device while well complications. In order to prevent a salt coating of the device details special coat is used. To control asphaltene sediments it is recommended to place shutoff valve close to the reservoir perforation zone, where the thermobaric conditions are not conducive to its appearance. Details and components are made of the special equipment and high-corrosion-resistant steels with high frequency working surfaces, polymers based on polyetheretherketones (PIC, Zedex etc.). The shutoff valve design is provided of the enlarged cross-section of flow channel that minimizes the emulsions impact on its work.

One of the most popular well complication affecting the operation of downhole pumping equipment, is the presence of mechanical impurities in the composition of extracted reservoir fluid. As packer equipment is used in the device for the reservoir protection, and fluid is taken from the annulus, then the operation of this equipment makes the risk of stagnant zones appearance in the interval between the packer and the perforated pipe, where solid phase particles of the reservoir will be taken oun. With the accumulation of a sufficient volume of the particles there is a risk to "grab" the packer and the problem of removing it from the well. In view of this equipment includes a special sludge trap installed between the hollow rod, and the pump unit, where the back pressure valve and the perforated pipe are placed. The function of this unit is to capture the mechanical impurities that come out of the perforated pipe with a well product extracted from the total fluid stream and settle on the packer. In addition, the sludge trap is an additional level of protection against ingress of foreign objects to the shutoff valve internal channel that could affect its functionality. As the sludge trap is installed above the hollow plunger, its lifting, revision and cleaning take place with each change of the pumping equipment.

In calculating of sludge trap sizes it was taken into account that during the operation of the pump the whole suspended solids volume is risen to the surface. In this case, the maximum possible volume of solids will settle in the sludge trap while the pump is stopped, and after a full stop fluid flow from the reservoir. As a result, the volume of mechanical impurities, potentially settling in sludge trap, will depend on the number of pumplong stops.

In carrying out the calculations it was assumed that during operation the volume of liquid between the pump and dynamic level is at rest (there is no fluid flow), and therefore, there is no mechanical impurities. Thus, when the pump is stopped mechanical impurities separation from the liquid $\left(V_{1}\right)$ (consist of two parts) occurs: the first one is between the perforated pipe holes and pump suction pipe, and the second one is determined by the influx from thereservoir after the pump stop. In calculations the ultimate worst case is considered, where the stop duration was sufficient to restore the level in the well to the static and loss of mechanical impurities from the fluid $V_{1}$. The volume of liquid that came in the well while the pump is stopped, for this case is calculated as the difference between the fluid volume in the annulus between the production casing and the tubing under static and dynamic levels. To calculate the volume of the particles entering the sludge trap during one stop, the following relationship is used:

$$
V_{M}=\frac{M \cdot V_{1}}{\rho_{\text {mid }}},
$$

where $M$ - mechanical impurities concentration, $\mathrm{g} / \mathrm{l} ; V_{1}$ - liquid volume where mechanical impurities separat, $1 ; \rho_{\text {mid }}-$ mechanical impurities density, g/l.

Meanwhile

$$
V_{1}=S\left(H_{D}-H_{S}+\Delta H\right),
$$


where $S$ - square of the annular gap between the production casing and the produsinf string, $\mathrm{m}^{2}$; $H_{D}$ - the dynamic level, $\mathrm{m} ; H_{S}$ - the static level, $\mathrm{m} ; \Delta H$ - distance between the perforated pipe holes and the pump suction pipe, $\mathrm{m}$.

Calculation of sludge trap volume is made on the basis of the limit values of the parameters affecting the volume of the drop-down mechanical impurities. Specific values of the parameters used to calculate the required sludge trap volume (Table).

Filling sludge trap results of calculations according to the different number of stops and mechanical impurities at various concentrations is shown in Fig. 5.

Initial parameters for the calculation of the sludge trap volume

\begin{tabular}{|l|c|}
\hline \multicolumn{1}{|c|}{ Parameter } & Value \\
\hline $\begin{array}{l}\text { The diameter of the production string (external / } \\
\text { internal), mm }\end{array}$ & $146 / 8$ \\
\hline The diameter of the tubing string (external), mm & 73 \\
\hline Pump lowering depth, $\mathrm{m}$ & 3300 \\
\hline $\begin{array}{l}\text { The distance between the perforated pipe holes and } \\
\text { the pump suction pipe, } \mathrm{m}\end{array}$ & 50 \\
\hline The dynamic level, $\mathrm{m}$ & 1300 \\
\hline The static level, $\mathrm{m}$ & 700 \\
\hline The content of mechanical impurities, mg/l & $\begin{array}{c}50 / 250 / \\
500 / 1000\end{array}$ \\
\hline Mechanical impurities density, g/l & 2000 \\
\hline
\end{tabular}

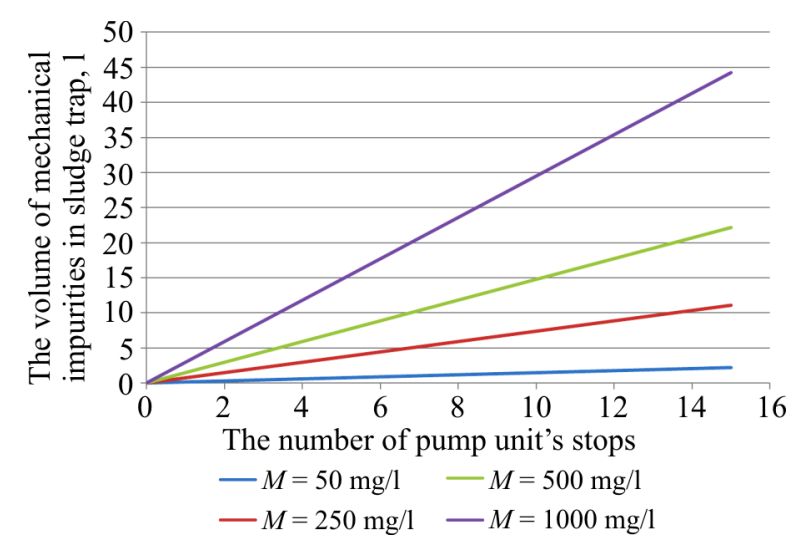

Fig. 5. Dependence of the filling sludge trap volume on the number of stops per year at different mechanical impurities concentration

Designing sludge trap was assumed that the number of stops in the course of the year must not exceed 10. Then, while the maximum volume of the mechanical impurities content $(1.000 \mathrm{mg} / \mathrm{l})$ expected volume of each year mechanical impurities should not exceed 30 liters. In accordance with the assumption the sludge trap design is proposed, its outer part of tubing 114, internal is made of tubing 73 . With sludge trap length of $10 \mathrm{~m}$, its internal volume will be about 36 , it will be filled after many year of work.

The basis of the valve design is ball valve principle. In the closed position the ball is pressed to the seat by pressure that provides a resistance to its opening (Fig. 6a). The valve opening is made by a drive mechanism which is actuated by pressing a hollow rod (Fig. 6b). The functionality of this mechanism depends on the load caused by the the differential pressure at the most stressed components - the drive axis, which pins are $6 \mathrm{~mm}$ in diameter, and the magnitude of the friction coefficient is between the materials of the sealing surfaces (steel, polyamide, Zedex).

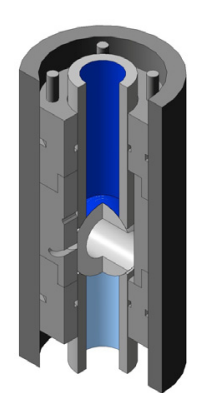

$a$

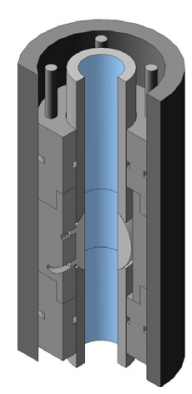

b
Fig. 6. 3Dmodel of the actuator (ball type) shutoff valve of MPRC: $a$ - an open position; $b$ - closed position

The rotation principle kinematics of the ball valve mechanism shown in Fig. 7.

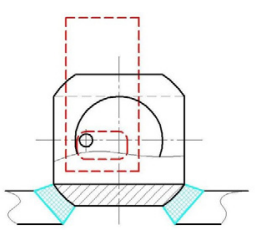

$a$

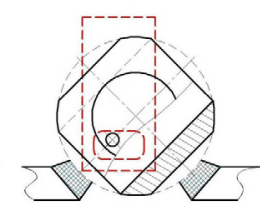

b

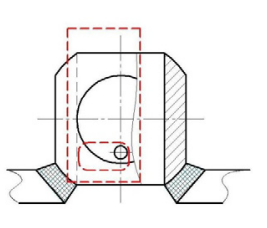

$c$
Fig. 7. Kinematic display image of the operating principle of the ball valve: $a$ - the valve is closed;

$b$ - the opening of the valve; $c$ - valve open

There is a diagram of the load shutoff valve on Fig. 8.

Calculation scheme for determining the necessary force on the actuator is shown in Fig. 9. 


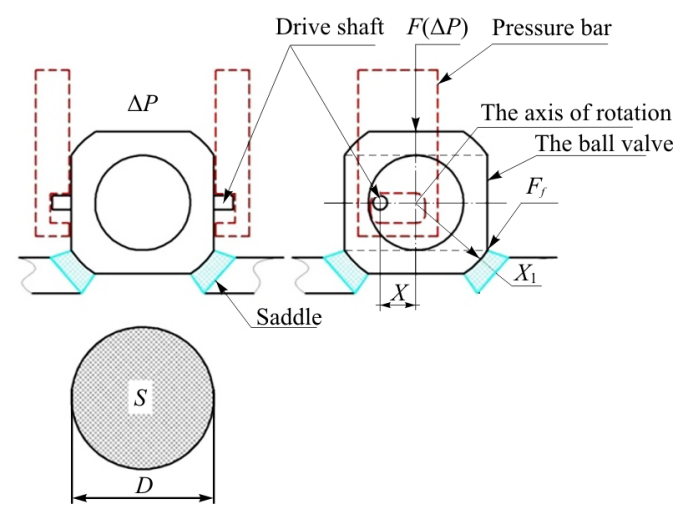

Fig. 8. The diagram of the load shutoff valve: $\Delta P$ - differential pressure at its locking element (ball mechanism); $S$ - the area where differential pressure $\Delta \mathrm{P}$ operates; $F(\Delta P)-$ the force acting on the valve (pressing the ball valve to the seat); $F_{f}$ - the frictional force that prevents the ball rotation (acts tangentially to the ball valve surface); $X$ - the shoulder, where the drive force operates (estimated value); $X_{1}$ - the radius of the ball or the shoulder where the friction force operates

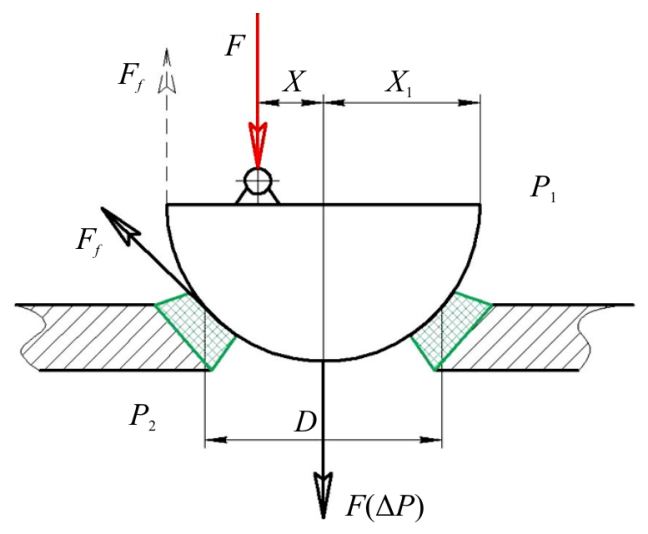

Fig. 9. Diagram for determining the necessary force to drive

The following input data are selected basing on the condition of having a differential pressure mechanism on the ball $\Delta P=10 \mathrm{MPa}$ : pressure over the ball mechanism $P_{1}=14 \mathrm{MPa}$; a pressure under ball mechanism $P_{2}=4 \mathrm{MPa}$. The following scantlings are selected basing on the geometric constraint of shutoff valve size:

- distance bet the rotation axis of the ball and the actuator axis $X=0.018 \mathrm{~m}$;

- the ball radius $X_{1}=0.036 \mathrm{~m}$;

- the seat diameter $D=0.056 \mathrm{~m}$;

- the seat area $S=0.00246176 \mathrm{~m}^{2}$.

The calculations were performed for the three variants of the sealing surfaces, which correspond to the following coefficients of friction: $K_{1}=0.5$ (steel on steel); $K_{2}=0.2$ (steel on polyamide); $K_{3}=0.1$ (steel on Zedex).

The formula is used to determine the force acting on the valve

$$
F(\Delta P)=\Delta P \cdot S .
$$

The frictional force preventing the ball rotation was determined by the formula

$$
F_{\mathrm{f}}=F(\Delta P) \cdot K,
$$

where $K$ - friction coefficient.

The force on the actuator was calculated by formula

$$
F=\frac{F_{\mathrm{f}} \cdot X_{1}}{X}
$$

The necessary force on the actuator was determined with regard to (3)-(5), that is: $F_{1}=24617.6 \mathrm{H}$ (for a pair of steel-steel); $F_{2}=9847 \mathrm{H}$ (for a pair of steel-polyamide); $F_{3}=4923.5 \mathrm{H}$ (for a pair of steel-Zedex).

Opening the valve the force $F$ operates on the drive axle, and it is defined by the formula (5). As the axes material steel $40 \mathrm{C} 13$ with allowable shear stress $\sigma=160 \mathrm{MPa}$ has been chosen. The axis diameter is $8 \mathrm{~mm}$, transverse dimension is $6 \mathrm{~mm}$.

Only calculation shear stresses are produced in view of the small axis transverse dimensions and the presence of significant shear forces. The shear stresses arising in the drive axes is determined by the formula

$$
\tau=\frac{F}{2 \cdot S_{\mathrm{a}}}
$$

where $F$ - force on the actuator; $S_{\mathrm{a}}-$ sectional area of the axis (as the construction of the valve is symmetrical, the load is distributed between two axles).

In view of (6) the amounts of shear stresses were determined in the drive axles, which were as follows:

$$
\begin{aligned}
& \tau_{1}=244 \mathrm{MPa} \text { (for a pair of steel-steel); } \\
& \tau_{2}=98 \mathrm{MPa} \text { (for a pair of steel-polyamide); } \\
& \tau_{3}=49 \mathrm{MPa} \text { (for a pair of steel-Zedex). }
\end{aligned}
$$

The calculations concluded that the strength conditions for the specified geometrical sizes in the study of pairs of steel-polyamide materials and steel-Zedex are executed, as the occurring in axis 
stresses do not exceed permissible for any given coefficient of friction.

\section{Conclusions}

The following features of the formation of the mechanical protection system ensuring its competitiveness in comparison with the known analogs of equipment and technologies are noted:

1. The device design guarantees reliable isolation of the under and above packer spaces, preventing the killing fluid getting into in the bottomhole formation zone.

2. The functionality of the equipment is provided both in the presence of well complications, and at different values of the differential pressure acting on the shitoff valve.

3. The design of the shutoff valve, which is part of the equipment, makes it possible, if necessary, to produce devices descent under packer for research the producing reservoir and geological and technical measures of the well.

4. The universal disign of the equipment expands field of application and the possibility of its use in configuration with any pump unit, depending on the well conditions.

5. The design of the protecting reservoir complex ensures simplicity and safety of its installation and activation.

At present a 3D-model and design documentation for MPRC nodes are developed. In the near future the production of prototyping equipment, carrying out of their factory test and after the test completion, will be organized. A number of interested oil companies agreed to conduct commercial well test after successful completion of modified equipment factory testing.

\section{References}

1. Gladkov P.D., Rogachev M.K. Vybor tekhnologicheskoi zhidkosti dlia glusheniia skvazhin pered podzemnym remontom na Priobskom neftianom mestorozhdenii [Selection of technological fluid for well-kill treatments on Priobskoye oil field]. Neftegazovoe delo: elektronnyi nauchnyi zhurnal, 2012, no.2, available at: http://ogbus.ru/authors/Gladkov/ Gladkov_2.pdf

2. Magadova L.A., Silin M.A., Gaevoi E.G. Zavorotnyi V.L., Eliseev D.Iu. Zhidkosti glusheniia i promyvki, sokhraniaiushchie kollektorskie svoistva plasta [Killing and Washing Fluids Preserving Reservoir Characteristics of the Formation]. Vremia koltiubinga, 2009, no.3(028), pp.72-80.

3. Demakhin S.A., Merkulov A.P., Kas'ianov D.N. Shchadiashchee glushenie skvazhin, kak osnova sokhraneniia kollektorskikh svoistv plasta [Sparing wells killing as the basis of preservation of reservoir properties]. Neftegazovaia vertikal', 2016, no.6, pp.94-96.

4. Cherygova M.A. Povyshenie effektivnosti promyvki skvazhin, oslozhnennykh asfal'tosmoloparofinovymi otlozheniiami, v usloviiakh anomal'no-nizkogo plastovogo davleniia razrabotkoi mnogofunktsional'noi tekhnologicheskoi zhid- kost'iu [Improving wells washing efficiency complicated with asphalt resin paraffin deposits in conditions of abnormally low reservoir pressure by development of multifunctional process fluid]: dis. ... kand. tekhn. nauk: 02.00.11. Moscow, 2016, 123 p.

5. Sarkisov N.M., Shishov S.V. Sposob zakrytiia klapana-otsekatelia pri izvlechenii elektrotsentrobezhnogo nasosa iz fontannoi skvazhiny i ustroistvo dlia ego osushchestvleniia [A method of shutoff valve closing when removing electrocentrifugal pump from natural flow well and device for its realization]: pat. 2204695 Ros. Federatsiia no. 2001105712/03; zaiavl. 28.02.2001; opubl. 20.05.2003.

6. Frantsev V.F. Skvazhinnyi klapan otsekatel' [Downhole shutoff valve]: pat. 2112863 Ros. Federatsiia no. 96100444/03; zaiavl. 09.01.1996; opubl. 10.06.1998.

7. Alekseev M.A., Bychkov N.A., Baldina T.R., Voevodkin V.L., Gebel' A.Ia., Krasnov V.A., Leifrid A.V., Mazein I.I., Opalev V.A., Tret'iakov O.V., Shalinov A.V., Shiriaev V.P. Otsekatel' stvola skvazhiny [Wellbore shutoff device]: pat. 2362872 Ros. Federatsiia no. 2007144245/03; patentoobladatel' LLC "LUKOIL-PERM"; zaiavl. 28.11.2007; opubl. 27.07.2009. 
8. Beketov S.B., Mashkov V.A. Skvazhinnyi klapan-otswkatel' [Wellbore shutoff valve]: pat. 2516708 Rossiiskaia Federatsiia no. 2012114031/03; patentoobladatel' ZAO "Gaztekhnologiia"; zaiavl. 10.04.2012; opubl. 20.10.2013.

9. Aminev M.Kh. Novye tekhnologii NPF "Paker" [New technologies SPF "Packer"]. Neftegazovaia vertikal', 2015, no.19, pp.62-65.

10. Kryganov P.V., Ponomarev A.K., Svalov A.V, Kornaeva D.A. Priamotochnyi skvazhinnyi klapanotsekatel' [Single-flow wellbore shutoff valve]: pat. 2564701 Ros. Federatsiia no. 2014134326/03; patentoobladatel' ZAO "Tsentr gidrodinamicheskikh issledovanii "INFORMPLAST"”; zaiavl. 22.08.2014; opubl. 10.10.2015.

11. Slivka P.I., Gabdulov R.R., Baiburin B.Kh. Sposob provedeniia podzemnogo remonta skvazhiny dlia smeny glubinno-nasosnogo oborudovaniia bez vozdeistviia na plast [Method of well servicing for changing downhole pumping equipment without formation stimulation]: pat. 2592903 Ros. Federatsiia no. 2015136826/03, MPK E 21 V 29/00, E 21 V 34/06, E 21 V 34/16; zaiavl. 28.08.2015; opubl. 27.07.2016.
12. Slivka P.I., Gabdulov R.R., Erastov S.A. Sposob otsecheniia plasta dlia provedeniia podzemnogo remonta bez glusheniia skvazhiny [Layer cutoff method for well servicing without well killing]: pat. 2531011 Ros. Federatsiia no. 2013120822/03, E 21 V 34/06; zaiavl. 16.05.2013; opubl. 20.10.2014.

13. RD 153-39.0-109-01. Metodicheskie ukazaniia po kompleksirovaniiu i etapnosti vypolneniia geofizicheskikh, gidrodinamicheskikh i geokhimicheskikh issledovanii neftianykh i neftegazovykh mestorozhdenii [Methodical guidelines for integrator and the phasing of geophysical, hydrodynamic and geochemical studies of oil and gas fields]. Moscow: Ministerstvo energetiki Rossiiskoi Federatsii, 2002.

14. PB 07-601-03. Okhrana nedr i geologomarksheiderskii kontrol'. Pravila okhrany nedr [Protection of mineral resources and geological survey control. Terms of protection of mineral resources]. Moscow: Nauchno-tekhnicheskii tsentr po bezopasnosti i promyshlennosti Gosgortekhnadzora Rossii, 2003.

\section{Список литературы}

1. Гладков П.Д., Рогачев М.К. Выбор технологической жидкости для глушения скважин перед подземным ремонтом на Приобском нефтяном месторождении // Нефтегазовое дело: электронный научный журнал. - 2012. - № 2. - URL: http://ogbus.ru/ authors/Gladkov/Gladkov_2.pdf (дата обращения: 12.07.2016).

2. Жидкости глушения и промывки, сохраняющие коллекторские свойства пласта / Л.А. Магадова, М.А. Силин, Е.Г. Гаевой, В.Л. Заворотный, Д.Ю. Елисеев // Время колтюбинга. - 2009. - № 3 (028). - С. 72-80.

3. Демахин С.А., Меркулов А.П., Касьянов Д.Н. Щадящее глушение скважин как основа сохранения коллекторских свойств пласта // Нефтегазовая вертикаль. - 2016. - № 6. - С. 94-96.

4. Черыгова М.А. Повышение эффективности промывки скважин, осложненных асфальтосмолопарафиновыми отложениями, в условиях аномально-низкого пластового давления многофункциональной технологической жидкостью: дис. ... канд. техн. наук: 02.00.11. - М., 2016. - 123 c.

5. Способ закрытия клапана-отсекателя при извлечении электроцентробежного насоса из фонтанной скважины и устройство для его осуществления: пат. 2204695 Рос. Федерация № 2001105712/03 / Саркисов Н.М., Шишов С.В.; заявл. 28.02.2001; опубл. 20.05.2003.

6. Скважинный клапан отсекатель: пат. 2112863 Рос. Федерация № 96100444/03 / Францев В.Ф.; заявл. 09.01.1996; опубл. 10.06.1998.

7. Отсекатель ствола скважины: пат. 2362872 Рос. Федерация № 2007144245/03 / Алексеев М.А., Бычков Н.А., Балдина Т.Р., Воеводкин В.Л., Гебель А.Я., Краснов В.А., Лейфрид А.В., Мазеин И.И., Опалев В.А., Третьяков О.В., Шалинов А.В., Ширяев В.П.; 
патентообладатель ООО «ЛУКОЙЛ-ПЕРМЬ»; заявл. 28.11.2007; опубл. 27.07.2009

8. Скважинный клапан-отсекатель: пат. 2516708 Рос. Федерация № 2012114031/03 / Бекетов С.Б., Машков В.А.; патентообладатель ЗАО «Газтехнология); заявл. 10.04.2012; опубл. 20.10.2013.

9. Аминев М.Х. Новые технологии НПФ «Пакер» // Нефтегазовая вертикаль. - 2015. № 19. - С. 62-65.

10. Прямоточный скважинный клапанотсекатель: пат. 2564701 Рос. Федерация № 2014134326/03 / Крыганов П.В., Пономарев А.К., Свалов А.В., Корнаева Д.А.; патентообладатель ЗАО «Центр гидродинамических исследований "ИНФОРМПЛАСТ”»; заявл. 22.08.2014; опубл. 10.10.2015.

11. Способ проведения подземного ремонта скважины для смены глубинно-насосного оборудования без воздействия на пласт: пат. 2592903 Рос. Федерация № 2015136826/03, МПК
Е 21 В 29/00, Е 21 В 34/06, Е 21 В 34/16 / Сливка П.И., Габдулов Р.Р., Байбурин Б.Х.; заявл. 28.08.2015; опубл. 27.07.2016.

12. Способ отсечения пласта для проведения подземного ремонта без глушения скважины: пат. 2531011 Рос. Федерация № 2013120822/03, Е 21 В 34/06 / Сливка П.И., Габдулов Р.Р., Ерастов С.А.; заявл. 16.05.2013; опубл. 20.10.2014.

13. РД 153-39.0-109-01. Методические указания по комплексированию и этапности выполнения геофизических, гидродинамических и геохимических исследований нефтяных и нефтегазовых месторождений. - М.: Министерство энергетики Российской Федерации, 2002.

14. ПБ 07-601-03. Охрана недр и геологомаркшейдерский контроль. Правила охраны недр. - М.: Научно-технический центр по безопасности и промышленности Госгортехнадзора России, 2003.

Please cite this article in English as:

Pepeliaev V.V., Korobkov I.L., Pepeliaev D.V., Nasyrov A.M., Galkin S.V. Mechanical system of layer protection and technology of its application to prevent clogging of bottomhole formation zone in performing geological and technical measures. Bulletin of PNRPU. Geology. Oil \& Gas Engineering \& Mining, 2016, vol.15, no.21, pp.329-338. DOI: 10.15593/2224-9923/2016.21.4

Просьба ссылаться на эту статью в русскоязычных источниках следующим образом:

Механический комплекс защиты пласта и технология его применения для предотвращения кольматации призабойной зоны пласта в процессе проведения геолого-технических мероприятий / В.В. Пепеляев, И.Л. Коробков, Д.В. Пепеляев, А.М. Насыров, С.В. Галкин // Вестник Пермского национального исследовательского политехнического университета. Геология. Нефтегазовое и горное дело. - 2016. - T.15, №21. - C.329-338. DOI: 10.15593/2224-9923/2016.21.4 